on all adult educationists to make themselves fully conversant with it.

From the foregoing it can be seen that the programme for education in the war-time Army is very comprehensive and has been tackled with ardour and enthusiasm despite desperately discouraging circumstances. Yet until September 1941 the men charged with operating this programme were keenly aware that they were achieving only a small part of their objective. The voluntary nature of the scheme meant that the educational facilities available were being used only by those people who would normally be engaged in some form of educational pursuit in their peace-time occupations, estimated at about 20 per cent of the whole. The other 80 per cent remained the hard core who displayed little interest and yet included most of the men for whom some form of education was greatly to be desired and who stood in greatest need.

To meet this need a measure of compulsion was necessary. This was first provided in September 1941, when the Army Bureau of Current Affairs was introduced. An official order was issued asking commanding officers to make arrangements for all the personnel on their establishments to be given instruction in current events for one hour each week during training hours. This hour was introduced in order that soldiers might keep abreast of current affairs and so know the purpose behind their duty. In order to surmount the difficulty of shortage of specialist instructors, it was decided that the scheme should be administered by regimental officers. Each officer was charged with carrying out the Army Bureau of Current Affairs hour in his particular platoon or section. As an aid the Army Bureau of Current Affairs issues. him with a brief each week on which to base his talk. These briefs are of two kinds and appear alternately. One, called "Current Affairs", aims at providing a background of knowledge against which current events can be assessed and understood. The other, "War", aims at providing a picture for the soldier of what is happening in the various theatres of war. The most important issue raised by the introduction of the Army Bureau of Current Affairs, however, was the expressed statement that each talk should form the basis of discussion and that all soldiers should be given opportunities to air their opinions freely, however far-fetched and unsubstantiated they might be. There is little need to dwell on the success of this scheme. It is enough to say that the Army Bureau of Current Affairs to-day is recognized as an integral part of Army life. Its establishment has undoubtedly assisted in promoting better relations between all ranks as well as in the maintenance of morale by disseminating facts about the high purpose of our cause.

It must be made clear that the introduction of the Army Bureau of Current Affairs did not mean the discontinuance of other educational activities. Far from it. These continued to flourish and were considerably extended by the compulsory nature of the Bureau. By last autumn Army education had made such progress that the Army Council agreed to introduce compulsion for other educational work. Accordingly a scheme was drawn up designed to be carried out during the period November 1942February 1943. At least three hours per week were to be allotted from training or working hours to education. It was suggested that three hours should be used in the following manner :

(a) One period to be devoted to educating the man as a soldier, for example, by providing instruction in map-reading, message writing, etc.

(b) One period to the education of the man as an individual. In this period men were to be encouraged to pursue subjects of their own choosing.

(c) The other period to be concerned with the education of the man as a citizen. This period is devoted to talks and discussions on the British mode of life, its institutions and methods of government, the British Commonwealth of Nations and British relations with the other members of the United Nations. To cover the citizenship period, monthly directives were issued and met with a very favourable reception.

This scheme has now come to an end and, where commanding officers have lent their support, has achieved considerable success. The citizenship period, in particular, has contributed so much to Army life that the War Office has decided that it shall continue, based on other topics, over the next few months at least.

"The greatest experiment in adult education" is a fitting description of such a gigantic scheme. But even this is only a prelude to the tremendous educational operations which must inevitably be introduced when victory comes and we are faced with the problems of demobilization. We can never be over-prepared. The place of science in this scheme was outlined in the columns of NaTuRE of Augast 16, 1942, p. 173, and a letter from Dr. Basil Yeaxlee in NATURE of September 6,1942 , p. 288 . It is hoped to discuss it more fully at a later date.

\section{INDIGENOUS MALARIA IN GREAT BRITAIN}

\section{By SIR ARTHUR MACNALTY, K.C.B.}

$\mathrm{D}^{\mathrm{R}}$ R. WILLARD C. RAPPLEYE, of Columbia University, has recently issued a warning that after the War the United States will probably be faced with the risk of epidemics of malaria, brought about by the return of malarial patients who have served in the Middle East and other theatres of war where the disease prevails.

In the United States, malaria has progressively diminished in extent and severity during the past eighty years. From Now England, where it once prevailed extensively, it has gradually disappeared, and in Philadelphia and along the valleys of the Delaware and Schuylkill Rivers, formerly hot-beds of malaria, the disease has become much more restricted. In Baltimore a few cases occur in the autumn, but the majority of the patients come from outlying districts and one or two of the inlets of Chesapeake Bay. Throughout the Southern States there are many regions in which malaria prevails; but here, too, the disease has diminished in prevalence and intensity. In temperate regions, like the central Atlantic States, there are only a few cases in the spring and a large number of cases in the autumn. In the Northwestern States malaria is almost unknown. It is rare on the Pacific coast, and in the region of the Great Lakes it prevails only in the Lake Erie and Lake St. Clair regions.

The introduction of fresh foci of infection from abroad would obviously be inimical to this favourable picture, and a similar danger to that foreshadowed by Dr. Rappleye faced Great Britain in the War of 
1914-18. The total number of locally contracted cases notified or discovered by special inquiry after September 1917 amounted to 330 , of which 38 were in the Navy, 224 in the Army and 68 in the civil population. It appears that 231 of these cases were contracted in 1917 and 99 in 1918. One interesting observation was the detection in 1918 of some patients in whom an infection contracted in the previous autumn had remained 'latent' during the winter. This was previously noted in England during the early years of last century ${ }^{1}$.

The sources of infection were multiple. In the Army, the origin of practically all the locally contracted cases was attributable to the presence in their immediate neighbourhood of relapsing cases of malaria among soldiers returned from eastern war areas, especially Salonika. The same source was usually responsible for cases among naval ratings and eivilians.

At certain English ports during 1917 and 1918, a potential source of infection of considerable importance was provided by the crews and passengers of transports and merchant ships which had called at Dakar, Sierra Leone and other ports on the west coast of Africa. During the War, malaria was exceptionally prevalent and severe in these ports. In 1917 more than five hundred cases of malignant tertian malaria were. introduced into England on ships from the West Coast and the Cameroons. Fortunately, the Anopheles of Great Britain do not act as efficient carriers of tropical malignant malaria ${ }^{2}$. In addition, it was found in some cases that malaria seemed attributable to infection, not from military foci, but from civilian patients in their immediate neighbourhood and, in a few instances, to civilian cases which had occurred before troops began to return from Salonika. Such an indigenous origin was ascribed to a considerable local spread of malaria in Kent. It was stated, for example, that so late as 1865-70 "nearly everyone in Queenborough suffered from ague". and that occasional cases had occurred every year since that time. The clinical symptoms of these Kentish cases were less severe than those of cases which were traced to an origin from military foci.

Malaria was formerly prevalent in Great Britain. In Sydenham's time agues were both frequent and fatal. James I and Oliver Cromwell both died of ague contracted in London. In. the eighteenth century malaria was endemic ; almost exclusively, along the eastern coast; in parts of Kent, Essex, Cambridgeshire, Norfolk, Suffolk and the East Riding of Yorkshire. Malaria prevailed then also in the eastern part of Scotland, especially in East Lothian, where the reapers at harvest-time were always attacked by it. In the nineteenth century the disease diminished greatly in Great Britain owing to the drainage of the fens and marshlands, which were brought under cultivation.

The presence of these endemic foci of malaria is not generally recognitzed by the medical profession and the public. They do, however, exist, and investigation by medical officers of the Ministry of Health in the intervening period between the last and the present War indicates that the distribution of indigenous malaria in England is about the same as that already described for the eighteenth century. Sinton and Shute advance sufficient reasons for believing that the density of Anopheles maculipennis offers the most likely explanation of this topographical distribution ${ }^{3}$.

Indigenous malaria, which usually takes the benign tertian form, is not common; the symptoms are usually mild, and instances of this type escape recog. nition unless malaria forms the subject of intensive investigation as in war-time. In peace-time there are always a certain number of imported cases in persons who have originally acquired malaria abroad; there were 354 such cases with 30 deaths in 1938, as contrasted with two indigenous cases in the same year. Such cases help, no doubt, to keep the strain of the benign tertian parasite persistent in England.

Although there are four species of Anophelines in Great Britain, only one species, Anopheles maculipennis, has so far been proved to be a carrier of malaria: this species is made up of a number of varieties or sub-species, which, while as yet indistinguishable in the adult stage, can be differentiated on the character of their eggs. Two varieties occur in England-one (var. messece) breeds in the fresh water of inland ponds and streams, the other (var. atroparvus) mainly in brackish water in coastal areas, but may occur in smaller numbers in inland waters. The latter variety is the chief carrier of malaria in Great Britain.

In peace-time the problem of the transmission of malaria by mosquitoes is seldom one of magnitude in Great Britain, and most measures against mosquitoes are usually undertaken in order to reduce their biting propensities. In war-time the problem naturally assumes a more serious aspect.

The successful policy pursued towards the end of the War of 1914-18 was based primarily on the early detection of all cases and carriers, followed by thorough treatment, protection from mosquitoes, and special supervision and control. On the military side this policy was adopted throughout Great Britain, and it was supplemented in a few areas by local anti-mosquito measures directed against breedingplaces. In view of these arrangements by the Army authorities, on the civil side exceptional precautionary measures, including notification, were at first limited to a few localities, which were selected either because cases of indigenous malaria had already occurred in them, or because they were places in which a considerable concentration of possible human malaria carriers coincided with an abundance of Anophelines. This limitation was justified in 1918, for only three cases of indigenous origin occurred outside the selected localities.

After the armistice of 1918, with demobilization, the possibility of local spread of malaria had to be watched. Accordingly the Local Government Board in January 1919 in a General Order (Public Health (Pneumonia, Malaria, Dysentery, etc.) Regulations, 1919) (afterwards amended by the Public Health (Infectious Diseases) Regulations, 1927) included clauses which imposed on local authorities and their officers throughout the country certain new powers and duties in regard to malaria prevention. Malaria cases, including those of demobilized ex-Service men, and others who have contracted infection abroad, are made notifiable in England and Wales. The medical officer of health in any district is empowered to investigate risks of local spread of malaria and to take any necessary action to prevent it. For example, when a man suffering from malaria occupies a house which is infested by Anophelines, at the cost of the local authority mosquito netting can be provided, suitable quinine treatment given, and proper advice afforded as to the precautions needed against the spread of infection. The medical officer of health, after confirming the diagnosis and the local origin of 
the case, should send the name and address to the Ministry of Health with all available particulars. All practical assistance is given by expert officers of the department to medical officers of health and medical practitioners in any case in which indigenous malaria is suspected. Blood films and other specialized examinations are arranged for.

The malarial work of the Ministry of Health was afterwards augmented by the provision of a malarial laboratory and centre at Horton Mental Hospital, Epsom, on the suggestion of Lieut.-Colonel S. P. James. The primary object of this unit was to provide treatment for general paralysis of the insane by induced malaria as initiated by Wagner-Jauregg of Vienna. The Board of Control, the London County Council and the authorities of Horton Hospital are closely associated with the Ministry in this work. The laboratory portion of the unit was under the control of Colonel James and afterwards under that of Lieut.-Colonel J. A. Sinton, assisted by Mr. P. G. Shute and laboratory assistants, while Dr. W. D. Nicol, medical superintendent of Horton Hospital, is in charge of the clinical side of the work. The unit further acts as a centre for the study and identification of mosquito nuisances in Great Britain, and a number of important papers and reports on the subject have been published by James, Nicol and Shute. Mr. Shute has paid visits to many districts in Great Britain and has advised on the control of Anophelines.

With all this administrative and scientific machinery to hand, it can be confidently anticipated that the Ministry of Health will safeguard the population of Great Britain against the risks of an increase of indigenous malaria after the present War as successfully as it did after the War of 1914-18.

1 Reports and Papers on Malaria contracted in England in 1918. Reps. to L.G.B. (N.S. No. 123.) (London: H.M. Stationery Office, 1919.) See also P. G. Shute: "Protracted Incubation Periods in Indigenous Cases of Malaria in England", J. Trop. $M e d$. and $H y g$. (July 15, 1939).

${ }^{2}$ Shute, P. G., "Failure to Infect English Specimens of Anopheles maculipennis var. atroparous with Certain Strains of Plasmodium falciparum of Tropical Origin", J. Trop. Med. and Hyg. (July 1, 1940 ).

3 Sinton, J. A., and Shute, P. G., "Memorandum on Measures for the Control of Mosquito Nuisances in Great Britain". Memo. 238/Med. Ministry of Health. Revised Edn. (London: H.M. Stationery Office, 1943.)

\section{OBITUARIES}

\section{Major Leonard Darwin}

WITH the death of Leonard Darwin on March 26, in the ninety-fourth year of his age, has passed the last of the five sons born to Charles Darwin. Taking the five sons in the order of their birth, William, the eldest, showed no aptitude for science; the second, George, the third, Francis, and the fifth, Horace, were gifted with creative faculties of a high order, all three becoming fellows of the Royal Society. Leonard, who came fourth in the series (he was born at Down House on January 15,1850 ), although he did much to further the cause of science, manifested none of those creative gifts which had been so liberally bestowed on his father and three brothers. Yet, in physical appearance, especially in later years when he grew a beard, in his attitude to life, and in the disposition of his mind, he bore a closer resemblance to his father than did any of his brothers. He had his father's honesty of expression, openness of mind, charitable disposition, subjugation of self, an excess of candour (" $\mathrm{d}-\mathrm{d}$ candour" his father named it on a certain occasion when irritated by unfair criticism) and also his father's happy sense of humour. He was completely devoid of personal ambition. There were not a few, however, who were ambitious on his behalf and felt that his services to science should have been recognized by election to the Royal Society. 'The University of Cambridge rightly bestowed on him an honorary doctorate of science.

In 1868 , at the age of eighteen, Leonard entered Woolwich, being second on the list at the entrance examination, a success which made his father exclaim: "I shall burst with pleasure at Leonard's success!" He served with the Royal Engineers for twenty years, retiring in 1890 on attaining his majority. During this time he was a member of two expeditions sent to observe the transit of Venusin New Zealand (1874) and in Queensland (1882)but for the greater part of his service he was engaged in the routine of office work or of acting as instructor at various staff colleges.

On retiring from the Army, Leonard Darwin entered public life, being elected Liberal Unionist member for the Lichfield Division of Staffordshire in the Anti-Home Rule election of 1892. In the election which followed three years later, he lost his seat and eventually retired from politics. Perhaps no one was less fitted for the rough and tumble of political life than Leonard Darwin. He was completely devoid of the "Party spirit". He looked on politics as the art of applying science to the problems of government. We see the trend of his mind at this time, in two publications which he issued at the close of his brief political career-on "Bimetallism" (1898), and on "Municipal Trading" (1903). He served (1913-20) as chairman of Bedford College for Women.

His real work in life came to him in 1911 on the death of his distinguished cousin, Sir Francis Galton. Galton had founded the Eugenics Society in 1908 (by the way, it is just sixty years since Galton coined the term 'eugenics'), and served as its honorary president until his death in 1911. Thereupon Leonard Darwin fathered the Eugenics Society, and continued to devote all his energies to promoting its welfare until 1929, when the late Sir Bernard Mallet took over the presidency, while Darwin continued to serve the Society as its honorary president. His attitude towards eugenies is given in detail in a book published in 1926, entitled "Need for Eugenic Reform".

In 1928 he withdrew from London, making his home at Cripps Corner, on the western outskirts of Ashdown Forest. $\mathrm{He}$ was twice married, first to Elizabeth Fraser, who died in 1898, and later to his cousin, Charlotte Mildred Langton, who died at Cripps Corner in 1940. There were no children by either marriage. Those who had the privilege of visiting at Cripps Corner carried away unforgettable memories of human life at its best.

Arthur Keith.

\section{Mr. H. D. Taylor}

Harold Dennis Taylor, a quiet man of simple tastes, varied interests, and wide knowledge, died on February 26, aged eighty-one. Probably best known as the inventor of the Cooke lens, he achieved much else that would have brought him fame.

Taylor was educated at St. Peter's School, York, and began to train as an architect, but was offered employment at the works of Thomas Cooke and Sons, scientific and surveying instrument makers, on 